\title{
An investigation of factors affecting SMEs performance: an Indonesian case
}

\author{
Cahya Mukti Dwi Kurnia1', Edy Raharja², and Yohanes Sugiarto² \\ ${ }^{1}$ Master of Management Program, Faculty of Economics and Business, Universitas Diponegoro, Indonesia \\ ${ }^{2}$ Department of Management, Faculty of Economics and Business, Universitas Diponegoro, Indonesia
}

\begin{abstract}
The objectives of this paper is to investigate factors that affecting SMEs performance. Particularly, our study examined the effect of entrepreneurial orientation, adaptability to external environment, and competitive advantage to SMEs performance. We also test the effect of entrepreneurial orientation and adaptability to external environment on SMEs competitive advantage. Results of structural equation modeling on 100 SMEs in Semarang, Central Java, Indonesia, suggested that entrepreneurial orientation and competitive advantage has a positive effect on SMEs business performance. However, our prediction that adaptability to external environment positively affect SMEs performance was not supported. Furthermore, our study also found that entrepreneurial orientation and adaptability to external environment positively affect SMEs competitive advantage.
\end{abstract}

\section{INTRODUCTION}

In recent years, business environment has been undergoing many changes and challenges that demand managers to struggle so their business can survive. The similar circumstances also faced by SMEs in Indonesia. With regard of their shortcomings, SMEs have to deal with changing business environment by maintaining their business performances.

Scholars and practitioners had applied some perspectives to develop organizations business performance. However, one of the most prominent perspective is resource-based view (RBV). RBV defines a company as a collection of resources and capabilities that can be used to create and develop competitive advantage. (Talaja, 2012). The competitive advantage is suggested as one of the most significant predictor of business performance.

Barney (1991) identifies that there are four characteristics of a resource that can maintain a company's competitive advantage, namely value, scarcity, imperfect imitation, and imperfect substitution. Nath et al., (2010) divides resources into two components namely visible and invisible. Visible resources consist of finance and physical assets, equipment, land and matrials. Unseen resources include human resources, client trust, company reputation and knowledge. Wu (2010) states that a company can use its ability to develop its resources to create competitive advantage.

Based on RBV theory, we proposed competitive advantage as the predictor of SMEs business performance. Furthermore, our study also proposed entrepreneurial orientation and adaptation to external environment as predictor of competitive advantage and business performance.

\section{LITERATURE REVIEW AND HYPOTHESES DEVELOPMENT}

\section{Business performance}

Company performance according to Prieto and Elena (2006) there are two types of financial performance and non-financial performance. The company's financial performance is influenced by many factors such as economic conditions, changes in government regulations that are likely to benefit a company compared to other companies, technological developments, changes in production costs and delivery of products or services due to macroeconomic shifts. Wadongo (2010) explains that there are several weaknesses in financial measurement, which are less accurate, neutral, summarized and irrelevant because of the delay in the accounting period. 
In addition, it only emphasizes on short, unbalanced periods and also fails to reflect strategic issues and performance.

\section{Entrepreneurial orientation, competitive advantage, and business performance}

Rauch and Frese (2009), explained that entrepreneurial orientation describes the enterprise-level strategic processes that are used to gain competitive advantage. The importance of entrepreneurial orientation on company performance to be considered, the entrepreneurial orientation can be a good measure to explore opportunities in the market and use them (Ireland, Hitt, and Sirmon, 2003). Zehir, Can, and Karaboga (2015) broke the orientation of entrepreneurship into five dimensions: innovation, risk taking, proactive attitude, aggressiveness, competition and autonomy. The attitude of innovation is the willingness to support creativity and experiment in introducing new products, the use of new technologies and research and development in creating new processes.

Business activities need to have Entrepreneurship-oriented attitudes especially for SMEs because having an entrepreneurial orientation attitude illustrates the strategic level of the enterprise that is used to gain competitive advantage. Entrepreneurial orientation at the company level as a reflection of a company's strategic orientation by influencing decisionmaking processes, practices, and activities that lead to new input (Lumpkin and Dess, 1996). In other side, some research on entrepreneurial orientation towards business performance is carried out by Perlines and Esteban (2017), Semrau et al., (2015), Rauch et al (2009) which states that business performance can be improved by increasing entrepreneurial orientation.

H1: Entrepreneurial orientation has positive effect on competitive advantage

H3: Entrepreneurial orientation has a positive effect on SME business performance

\section{Adaptation of the external business environment, competitive advantage, and business performance}

Pearce and Robinson (2008), explained that the external environment of a company consists of a remote environment, industrial environment, and operating environment. Kreiser et al.,
(2010) added that national culture influences organizational risk taking and proactive corporate behavior has important managerial implications. Murzidah and Thomson (2011) state that including the external environment are customers, competitors, government regulations, and the economy.

Reeves and Deimler (2012) argued that the companies ability to respond the change signals and then quickly refine or reinvent their business model could enhance the companies competitive advantage. In other side, Winata (2015) and Njanja (2012) reported in his research that the business environment brought considerable influence on business performance.

\section{H2: Adaptation of the external business environment has a positive effect on competitive advantage}

H4: Adaptation of the external business environment has a positive effect on SME business performance

\section{Competitive advantage and business performance}

Ward and Rebecca (2000) share strategies of competitive advantage based on cost and differentiation. Cost measurement prioritizes operating efficiency, competitive prices, purchasing raw materials, minimizing expenses, reducing features, and reducing production costs. Competitive strategy differentiation is more concerned with product development in business units, brand identification, innovation in marketing techniques and methods, innovation in products and services, advertising, reputation in the industry and forecasting market growth.

Hill and Jones (2010) stated that the primacy of the orientation of competitive advantage in a company is efficiency, quality, innovation and accountability to customers. Innovation is one of the current competitive environments and is one of the main sources of competitive advantage of SMEs (Zuzák, 2011). Svarova and Virchota (2014) argue that competitive advantage is divided into two, namely external and internal. External competitive advantage consists of flexibility, product range, customer satisfaction, etc. While internal competitive advantage is quality of staff, quality of work, knowledge etc.

Business sustainability is a necessity achieved by business organizations. Competitive advantage is a way for businesses 
to continue both large companies and small companies, by implementing a superior partnership strategy will increase the competitiveness of a business. Barney (2010) companies that can create added value in the market or industry compared to competitors in similar actions are competitive advantages. Companies that offer better value than competitors so that they benefit from competitive advantage (Kotler et al., 2005). Prakash's (2014) research shows that competitive advantage strategies affect business performance. Kuo et al .'s research (2017) shows that companies with greater dynamic capabilities are easier to directly increase competitive advantage and indirectly have an impact on organizational performance.

H5: Competitive advantage has a positive effect on SME business performance

\section{METHODS}

The sample of this study is the owners or managers of SMEs of matrial shops in Semarang, Central Java, Indonesia, with the number of respondents as many as 100. Data was collected using a questionnaire tool. Data analysis used Structural Equation Modeling (SEM) techniques which are processed using SmartPLS 3 software to test models and relationships between variables and indicators.

\section{RESULTS AND DISCUSSION}

This study consisted of five hypotheses, with each of them was tested using t-statistic value from the causal processing relationship of Structural Equation Modeling (SEM) as shown in table 1.

The test results obtained the results of $t$ - count that are above the t-table or with a probability smaller than 0.05 as many as four and the original sample that shows all positive values so that four hypotheses are accepted.

The testing of hypothesis 1 is shown by the original sample value of 0.446 which indicates that the direction of the relationship is positive and the t-count value greater than the value of the t-table is equal to 4.828 which means that the entrepreneurial orientation has a significant effect. This result shows that entrepreneurial orientation has a positive effect on competitive advantage. Thus, hypothesis 1 is supported. As suggested by Lumpkin and Dess (1996), entrepreneurial orientation foster the competitive advantage by improve decisionmaking processes, practices, and activities that lead to new input.

The testing of hypothesis 2 is shown by the original sample value of 0.227 which indicates that the direction of the relationship is positive and the t-count value greater than the t-table value is 2.600 which means that the adaptation of the external business environment has a significant effect. This result shows that the adaptation of the external business environment have a positive effect on competitive advantage. Thus, hypothesis 2 is supported. It corresponds with Reeves and Deimler (2012) study which argued that the companies ability to respond the change signals and then quickly refine or reinvent their business model could enhance the companies competitive advantage.

The testing of hypothesis 3 is shown by the original sample value of 0.555 indicating that the direction of the relationship is positive and the t-count value is greater than the value of the t-table that is equal to 10.715 which means that entrepreneurial orientation has a significant effect on business performance. This results

Tabel 1.

Path Cofficients

\begin{tabular}{|c|c|c|c|c|c|}
\hline Relationship Betwen Variable & $\begin{array}{c}\text { Original } \\
\text { Sample (O) }\end{array}$ & $\begin{array}{l}\text { Sample } \\
\text { Mean (M) }\end{array}$ & $\begin{array}{l}\text { Standard } \\
\text { Deviation }\end{array}$ & $\begin{array}{c}\mathbf{t} \\
\text { Statistics }\end{array}$ & $\begin{array}{c}\mathbf{p} \\
\text { Values }\end{array}$ \\
\hline $\begin{array}{l}\text { Entrepreneurial Orientations } \\
\text { Competitive Advantage }\end{array}$ & 0,446 & 0,454 & 0,092 & 4,828 & 0,000 \\
\hline $\begin{array}{l}\text { Adaptation of the External Business } \\
\text { Environment --> Competitive Advantage }\end{array}$ & 0,277 & 0,283 & 0,106 & 2,600 & 0,010 \\
\hline $\begin{array}{l}\text { Entrepreneurial Orientations } \\
\text { Business Performance }\end{array}$ & 0,555 & 0,554 & 0,052 & 10,715 & 0,000 \\
\hline $\begin{array}{l}\text { Adaptation of the External Business } \\
\text { Environment --> Business Performance }\end{array}$ & 0,079 & 0,068 & 0,078 & 1,003 & 0,316 \\
\hline $\begin{array}{l}\text { Competitive Advantage --> Business } \\
\text { Performance }\end{array}$ & 0,346 & 0,355 & 0,074 & 4,701 & 0,000 \\
\hline
\end{tabular}


shows that entrepreneurial orientation has a positive effect on business performance. Thus, hypothesis 3 is supported. It also gievs another support for study by Perlines and Esteban (2017), Semrau et al., (2015), and Rauch et al (2009).

The testing of hypothesis 4 is shown by the original sample value of 0.079 which indicates that the direction of the relationship is positive but the $t$-count value lower than the t-table value is equal to 1.003 which means that the adaptation of the external business environment has no significant effect. This result shows that adaptation of the external business environment do not affect business performance. The most plausible explanation the hypothesis 4 is not supported could be rooted from the sample issue. Given that the sample of our study is matrial shops which do not intensively affected by external environment, the managers then perceived that external environment adaptability is not the significant predictor of business performance.

The testing the effect of competitive advantage on business performance is shown by a positive original sample value of 0.346 so the direction of the relationship is positive and the $\mathrm{t}$-count value is greater than the t-table value of 4.701, which means that competitive advantage has a significant effect on business performance. This result shows that competitive advantage have a positive effect on business performance. It is in line with findings by Prakash (2014) who found that competitive advantage strategies affect business performance.

\section{CONCLUSIONS}

Our study found that high entrepreneurial orientation increases competitive advantage of SMEs. An entrepreneurial orientation is needed to strengthen its competitive advantage by planning, determining decisions and direct supervision for the creation and development of its competitive advantages.

Although our prediction that adaptation of external business environment is a positive determinant for business performance was not supported, our study found that adaptation of external business environment increases competitive advantage. Adaptation of the external business environment needs to be improved in a SMEs to strengthen its competitive advantage by observing business changes and adjusting its competitive advantage to win the competition.
Another finding also suggested that high entrepreneurial orientation improves business performance. A high entrepreneurial orientation is required by SMEs to improve business performance because business performance is determined by the attitude of the business owner/person in charge who has the courage to make decisions, direct involvement in the business will improve its business performance.

Our last finding indicated that competitive advantage improves business performance. SMEs should enhances competitive advantage by offering more value to customers which consists of service excellence, delivery excellence, low prices and marketing excellence so that it has an impact on improving its business performance.

\section{REFERENCES}

Barney, JB, 1991, "Firm Resources and sustained Competitive Advantage", Journal Management, Vol.17, No.1, pp. 99-120

Hertawan, Yudi, 2015," Pengaruh Lingkungan Bisnis Dan Kepemimpinan Stratejik Terhadap Strategi Bersaing dan Kinerja Bisnis (Studi Pada Hotel Non Bintang di Provinsi Kepulauan Riau) ", Jurnal Bisnis Dan Manajemen. Vol.XVI, No 2, pp.90-108

Hill, $\mathrm{CH}$ and $\mathrm{W}$ Jones GR, 2010, Strategic Management Theory: An Integrated Approach, Grada, Praha

Ireland, R. D., Hitt, M. A., and Sirmon, D. G. 2003. A model of strategic entrepreneurship: The construct and its dimensions. Journal of management, 29(6), 963-989.

Kotler, P., Wong, V., Sunders, J., Amstrong, G, 2005, Principles of Marketing 4th edition. Prentice Hall

Kreiser, Patrick M., Marino, Louis D., Dickson, Pat., Weaver, K Mark, 2010, "Cultural Influences on Entrepreneurial Orientation: The Impact of National Culture on Risk Taking and Proactiveness in SME's", Entrepreneurship Theory and Practice, pp.959-984

Kuo, Szu-Yu and Pei-Chun Lin., Chin-Shan Lu, 2017, "The Effects of Dynamic Capabilities, $\begin{array}{ll}\text { Service Capabilities, Competitive } & \\ \text { Advantage, and Kenyen Case", }\end{array}$ International Journal of Business and Management, Vol.7, No.3, pp.194-205

Lumpkin, G.T., and Dess G.G, 1996, "Clarifying The Entrepreneurial Orientation Construct and Linking it to Performance", Academy of Management Review, Vol.21, No.1, pp.135173 
Murzidah, Ahmad Murad and John Doughlas Thomson, 2011, External Environment Factors Influencing the Technology Adoption-Diffusion Decision in Malaysia Manufacturing Small Medium Enterprices (SMEs), Progress in Business Innovation \& Technology Management, Vol.1, pp.013- 002.

Nath, P., Nachiappan,S., Ramanathan,R., 2010. "The Impact of Marketing Capability, Operations Capability and Diversification Strategy on Performance Resources Based View", India Market Management, Vol.39, No.2, pp.317-329

Njanja, WL, 2012,"The Effect of the External Environment on Internal Management Strategies within Micro, Small and Medium Enterprises: Kenyen Case", International Journal of Business and Management, Vol.7, No.3, pp.194-205

Pearce, John A and Richard B Robinson, 2008, Manajemen Strategis: Formulasi, Implementasi dan Pengendalian, Penerbit Salemba Empat, Jakarta

Perlines, Felipe Hernandez and Estaben ManceboLozano, 2016, "Conditional Mediation Of Competitive Strategy And Environment In International Entrepreneurial Orientastion Of Family Business ", Europen Journal Of Family Business, Vol.6, pp.86-98

Prakash, Gyan, 2014, " QoS In The Internal Supplay Chain: The Next Lever of Competitive Advantage and Organisational Performance", Production Planningand Control: The Management of Operations, Vol. 25, No.7, pp.572-591

Prieto, IM and Elena Revilla, 2006, "Learning Capability and Business Performance: A NonFinancial and Financial Assessment", The Learning Organization, Vol.13, No.2, pp.166-185

Rauch, A and Wiklund J., Lumpkin G. T., Frese M, 2009, "Entrepreneurial Orientation and Business Performance: an Assessment of Past Research and Suggestions For The Future", Entrepreneurship: Theory and Practice, Vol.33, No.3, pp.761-787

Reeves, M., and Deimler, M. 2012. Adaptability: The new competitive advantage. Own the Future: 50 Ways to Win from the Boston Consulting Group, 19-26.

Semrau, Thorsten., Tina Ambos., Sascha Kraus, 2015, "Entrepreneurial Orientation and SME Performance Across Societal Cultures: An International Study", Journal of Business Research, xxxx (article in press)

Svarova, Monika and Jaroslav Virchota, 2014, "Influence of Competitive Advantage on Formulation Business Strategy", Procedia
Economics And Finance, Vol.12, pp.687694.

Talaja, A, 2012, "Testing VRIIN Framework: Resource Value and Rareness as Sources of Competitive Advantage and Above Average Performance", Journal Management, Vol.17, No.2, pp.51-64

Wadongo, B and Odhuno E., Kambona O., Othuan L, 2010, "Key Performance Indicators in The Kenyan Hospitality Industry: A Managerial Perspective", Benchmarking: an International Journal, Vol.17, No.6, pp.858875

Ward, PT and Rebecca D, 2000, "Manufacturing Strategy in Context: Enviroment, Competitive Strategy and Manufacturing Strategy", Journal of Operations Management, Vol.18, pp.123-138

Winata, Felix Andhy., Miyasto., J Sugiarto, 2015, Pengaruh Kualitas Hubungan dan Kemampuan Adaptasi Terhadap Lingkungan yang Mempengaruhi Keunggulan Bersaing dan Implikasinya Pada Kinerja Perusahaan (Studi Pada PT AGA PRATAMA), Tesis Program Pasca Sarjana Magister Manajemen Universitas Diponegoro (tidak dipublikasikan)

Wu,LY, 2010, "Applicability of the Resource-Based and Dynamic-Capability Views Under Environmental Votality. Journal Business Research, Vol.63, No.1, pp.27-31

Zehir, C., Can, E., \& Karaboga, T. 2015. Linking entrepreneurial orientation to firm performance: the role of differentiation strategy and innovation performance. Procedia-Social and Behavioral Sciences, 210, 358-367.

Zuzák, R, 2011, Strategické Řizení Podniku, Grada, Praha 